International Journal of Agriculture and Environmental Research

ISSN: 2455-6939

Volume: 06, Issue: 03 "May-June 2020"

\title{
PECULIARITIES OF WATER RESOURCES USE IN UZBEKISTAN
}

\author{
${ }^{1}$ Olim Khamitovich Raximov, ${ }^{2}$ T. S. Cuesta and ${ }^{3}$ Obidjon Hafizovich Khamidov \\ ${ }^{1} \mathrm{PhD}$ Student, Agricultural and Forestry Engineering Department, University of Santiago de Compostela and \\ Professor in Faculty of Economics and Tourism, Bukhara State University. \\ ${ }^{2}$ Professor, Agricultural and Forestry Engineering Department, University of Santiago de Compostela. \\ Higher Polytechnic Engineering School, Campus Universitario s/n Lugo 27003, Spain. \\ ${ }^{3}$ Professor, Faculty of Economics and Tourism, Bukhara State University.
}

DOI: 10.46609/IJAER.2020.v06i03.009 URL: https://doi.org/10.46609/IJAER.2020.v06i03.009

\begin{abstract}
The use of water resources in Uzbekistan has a long history and character. According to historical data, land irrigation has developed in the eastern countries, mainly from the upper reaches of the rivers to the lower reaches. The development of irrigated agriculture in ancient times had three stages. Initially, primary simple irrigation was carried out in the existing tribes. In a second stage, as a result of the formation of slave communities, agricultural societies began to build relatively larger canals. Finally, centralized slavery states emerged, which built and expanded irrigation networks. These are the stages of their water intake from these irrigation sources and centralized management. The achievements in the field of irrigation in the Central Asian region have set an example for other countries and stimulated their development. These peculiar features of water use and its history are analysed in the article.
\end{abstract}

Keywords: Water resources, canals, irrigation, agriculture, land reclamation

\section{INTRODUCTION}

The study area of this document is the Republic of Uzbekistan, located in Central Asia (Fig. 1). The most advanced period of agriculture coincided with the emergence of centralized slavery states, the development of which was mainly associated with the development of agriculture (Bartold, 1925). Great work has been done in Central Asia, large-scale irrigation networks have been built in Bactria (upper part of the Amu Darya river), Sogdiana (Zarafshan oasis) and Khorezm. 


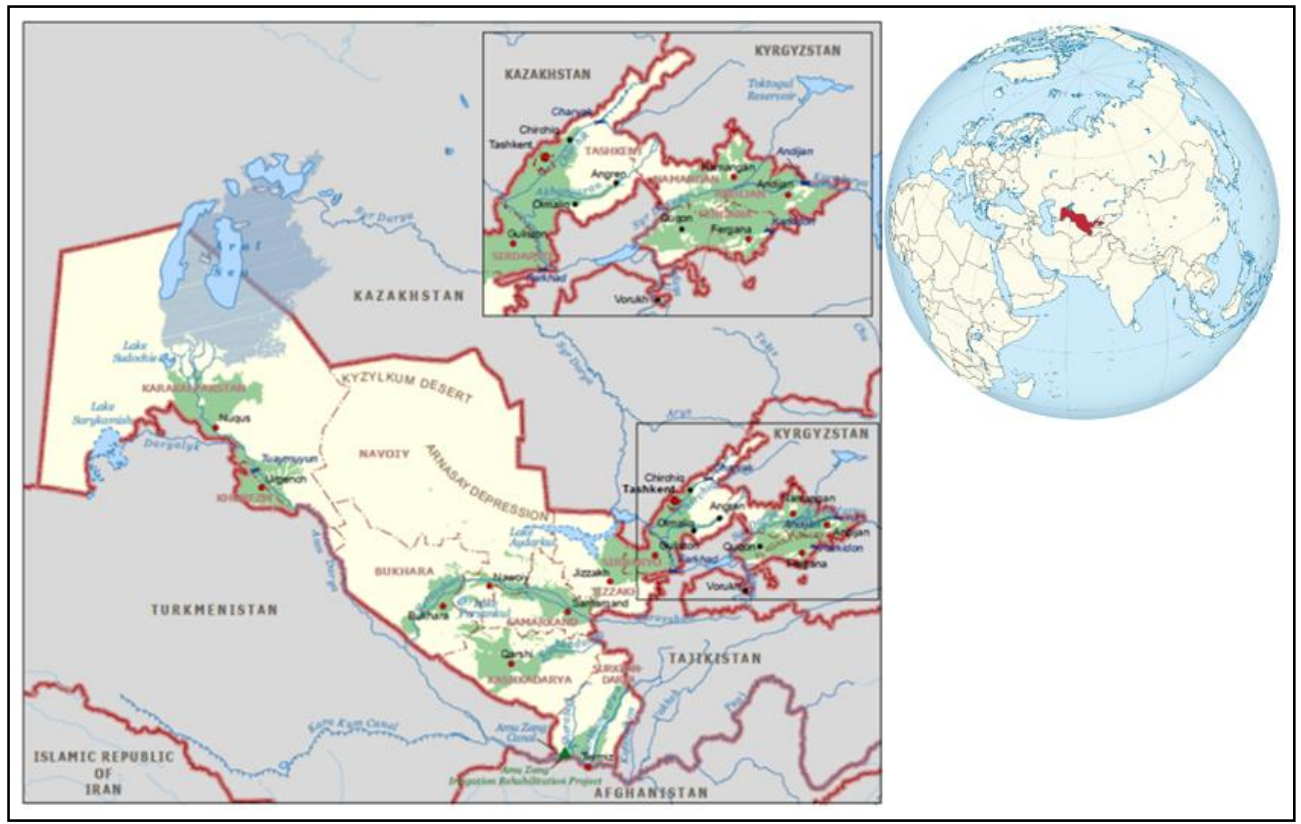

Fig. 1: Map showing the location of the Republic of Uzbekistan (FAO, 2012)

According to Askarov (1981), the achievements in the field of irrigation in the Central Asian region have set an example for other countries and stimulated their development. The Murgab irrigation network (VI-VIII centuries) laid the foundation for the irrigation of the lands of Basna for the Arabs. The Khorezm oasis is one of the first in the world to start irrigation.

Water is a vital element for all spheres of socio-economic activity, a vital natural resource for the life and activity of households, agricultural producers and other enterprises, as well as for maintaining the ecological balance (Abdullaev et al., 2009). According to the UN classification, Uzbekistan is one of the countries experiencing water shortages (FAO, 2012). It is estimated that a $10-20 \%$ reduction in water supply could have serious consequences for the size and size of irrigated land. This decrease would lead to a decrease in national income.

Within this framework, the main objective of the development of water resources in the Republic of Uzbekistan is to create the necessary conditions to meet the growing needs of the population (Rahimov and Abdughaniyev, 2009). These needs are very important in the sectors of the economy and the environment. It is important to ensure effective management and rational use of water resources. Furthermore, it is worth highlighting the improvement in the recovery of irrigated lands, the increased efficiency in the use of water resources, water management and food security in the face of growing deficits and global climate change. 
The future of Uzbekistan's water economy is determined by efforts in the field of water resource management and the importance of international cooperation in the use of transboundary rivers (Sokolov, 2019). In this case, climate change is an important factor in guaranteeing the supply and security of water in the future.

In this scenario, the decrease in water supply is worrisome due to the reduction in the contributions of rivers and groundwater. Therefore, to meet the economic and environmental needs of water, it is necessary to increase efficiency (Rakhimov and Yavmutov, 2019). The application of integrated water management practices can lead to greater cooperation between different users.

The main source of water resources for irrigation is agriculture, which represents up to $90 \%$ of water consumption in the country. Farmers have great potential to increase water use efficiency and on-farm productivity. It is necessary to undertake the improvement and modernization of irrigation infrastructures.

\section{Characterisation of the area}

The study area of this paper is the Republic of Uzbekistan. Uzbekistan covers an area of 447.400 $\mathrm{km}^{2}$ and it is located in Central Asia. It limits Kazakhstan to the north and northeast, Turkmenistan to the southwest, Afghanistan to the south, Tajikistan to the southeast and Kyrgyzstan to the northeast. (Fig. 1). The study area is furrowed by the Syr Darya river, which rises in the Tian Shan mountain range, in Kyrgyzstan, and the Amu Darya river, which rises in the Pamir, between Afghanistan, China and Tajikistan (Kogay, 1969). Both rivers flow into the Aral Sea, whose desertification is the greatest ecological catastrophe in the region (Bekchanov et al., 2018). The Kyzylkum desert, which is also part of Kazakhstan, occupies much of the northern and central plains of Uzbekistan.

The main agricultural areas border the Syr Darya and Amu Darya rivers, highlighting the Ferganá valley, the Zerafshan river and Chirchik river basins, and some areas of the Amu Darya basin (Fig. 2). 


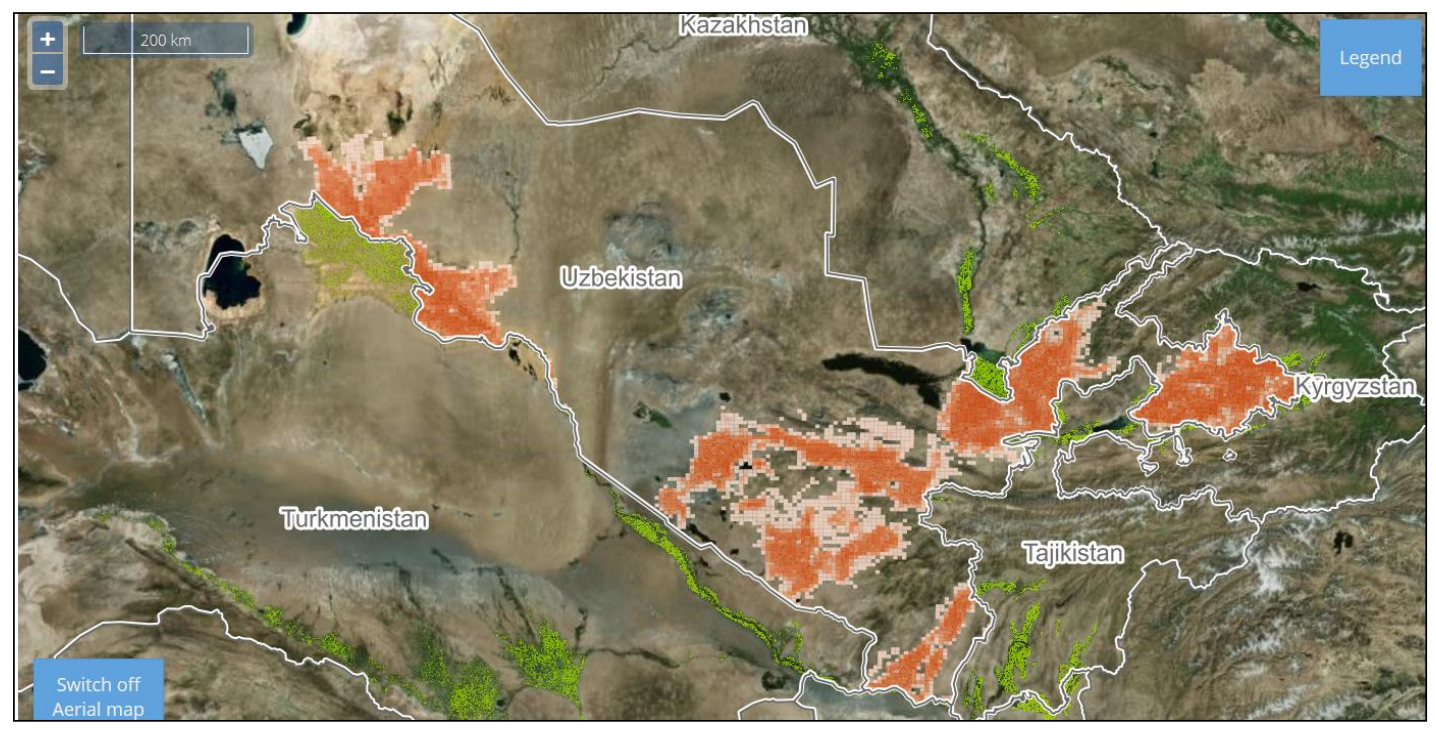

Fig. 2: Map showing the location of the main irrigated areas (CAWater-IS, 2020)

The climate is continental; arid/deserts cover over $60 \%$ of the territory (Toshov and Mirzaev, 2016). Average annual rainfall is $264 \mathrm{~mm}$, ranging from less that $97 \mathrm{~mm}$ in the northwest to 425 $\mathrm{mm}$ in the mountainous regions in the centre and south. In the Fergana valley, average annual rainfall varies between 98 and $502 \mathrm{~mm}$, while in the Tashkent vilayat, it varies between 295 and $878 \mathrm{~mm}$. Rainfall occurs during the winter, mainly between October and April. There are high temperatures $42-47^{\circ} \mathrm{C}$ on the plains and $25-30^{\circ} \mathrm{C}$ in the mountainous regions in July, and low temperatures in winter, minus $11^{\circ} \mathrm{C}$ in the north and $2-3^{\circ} \mathrm{C}$ in the south in January. Because of frequent frosts, between late September and April, only one crop a year can be grown. In favourable years, however, double-cropping of vegetables with a short growing period is possible.

In 2018, the cultivated area was an estimated 4,65 million ha, of which 92,5\% was under temporary crops and 7,5\% under permanent (Rakhimov and Yavmutov, 2019). Only 18\% of the cultivable area, an estimated 25,4 million ha, is cultivated because of the water shortage. Agriculture in Uzbekistan represents 19,2\% of GDP, 46\% of employment and 60\% of foreign exchange earnings (Rahimov and Abdughaniyev, 2009). The base of agricultural production is irrigated agriculture with almost $82 \%$ of agricultural land. Cotton and wheat are the main crops, although it is also worth mentioning the cultivation of cherries and grapefruits for their high added value (Abdullaev et al., 2009). 
International Journal of Agriculture and Environmental Research

ISSN: 2455-6939

Volume: 06, Issue: 03 "May-June 2020"

\section{LITERATURE REVIEW}

According to well-known historians and archeologists (Bartold, 1925; Yakubovsky and Nekrasov, 1930; Tolstov, 1962; Gulyamov, 1979), the construction of canals and irrigation took place here in the mid-2000s BC. The cultivation of these lands began in the rivers of the Amu Darya, and later by drawing water from natural streams. In the first centuries AD, agriculture and culture developed in Khorezm, during which time the lands belonging to the Daryol river and Daudan tributaries of the Amu Darya river were developed.

The biggest achievement in the development of the lands of the Khorezm oasis is the introduction of a two-tier system of land reclamation. In $138 \mathrm{BC}$, the Chinese traveler Zhang Qian wrote that there were 70 cities in the Fergana Valley with a population of 300,000 (Tolstov, 1962). Until the 3rd century AD, the irrigation sector was highly developed here. They planted grapes, rice, wheat and other crops during this period and had an artificial irrigation system. An artificial irrigation system is also developed in Khorezm. The Chinese called the country "Kanguy", which means "land of canals".

The Sassanid state was established at the foot of the Surkhandarya River, and its reign lasted 400 years. In the 6th-8th centuries BC, in Central Asia, states like Khorezm, Sogdiana, Tokharistan appeared. During this period, the culture of agriculture, the activities of the irrigation network developed more widely (Gulyamov, 1979). Large and small underground channels were built. In the first centuries AD, a large branch canal was built on the basis of the Tuprakkala canal. Ghaznabod - Irrigated lands have been expanded by taking water from the Chermen-yob canal. In the 3rd century, the West Qiyat Canal was built. In the 6th century, irrigated agriculture was revived in the oases around the Guldursun and Burgutkala canals.

According to Greek historians, in the III-II centuries BC, large canals were built around Tashkent. According to Arab geographers, the Shosh (Tashkent oasis) had a densely populated area of about 50 ha, covered with orchards and vineyards (Yakubovsky and Nekrasov, 1930; Tolstov, 1962). Some of them, for example, Biskent (Pskent), Ferkent (Parkent), Zarekent (Zarkent) are still preserved. Traces of Campirdevol and Bozsuv have survived to this day. Some ancient channels, such as Zach, Solor, are still called by their old names. 700-800 years ago, at the confluence of the Arisdarya and the Syrdarya, the ruins of the great trading city of Otrar still exist.

The agricultural culture of the Fergana Valley is widely developed in the Chatkal and Fergana systems around the small canals of the Karadarya that flow into the Norin. Mountain rivers were used for full irrigation purposes in the earlier X centuries AD. Cities and villages were built on their shores: in Kosonsoy, Akhsikent (Kosonsoy), Margilan (Margilansay), Khojand, Osh 
International Journal of Agriculture and Environmental Research

ISSN: 2455-6939

Volume: 06, Issue: 03 "May-June 2020"

(Akbora). The Arabs who conquered Central Asia in the eighth century witnessed the flourishing of the irrigation networks of these lands, and skilled local irrigators were taken to Mecca and other parts of the country to build facilities for this purpose (Askarov, 1981).

During the Arab Khaliphate, the Tahirids (late ninth century) were established in Khorasan (northern Iran) and the Samanids (tenth century) in Movarounnahr (between the Amu Darya and Syrdarya). During these periods, the crisis-ridden irrigation system was rebuilt and agriculture flourished. In the IX century in Gurganj (Old Urgench), in the lower reaches of the Amu Darya, the development of irrigation began. In the lower part of the Ghaznabad (Madra) canals, agriculture was restored, during which the Shavat (Shohobod) and Buva canals were built (Tolstov, 1962). In the 10th century, two canals were dug on the left bank of the Amu Darya from the Haykanas (Khiva) canal. In the XII - XIII centuries in Khorezm there was a centralization of the irrigation system. The Ghaznabad canal was extended to Shohsanam.

For the next three centuries, Central Asia was divided into small khanates, and the economic and social life of the population was in crisis due to civil wars. Irrigation facilities were damaged, and agriculture was completely shut down (Abdullaev et al., 2009).

According Rakhimov and Yavmutov (2019), uzbek water management is currently facing new challenges. These are climate change, increased demand for food due to increased population and real incomes, and the development of new industrial and urban areas that require additional water resources. The price of irrigated land is growing in Uzbekistan and around the world. Irrigated land covers $14 \%$ of the world's arable land and feeds half of the world's population. Also in our country, these lands are extremely valuable. In Uzbekistan, only 4,6\% of arable land is irrigated but produces $98 \%$ of agricultural products.

\section{Threats due to climate change and consequences on regional relations}

Climate change is accompanied by an increase in ambient temperature during the hot summer months and an increase in the number of years of water scarcity. This situation causes the region to intensify floods and other natural phenomena. This is due to the increased intensity of rainfall during certain periods of the year (Sokolov, 2019).

As in Central Asia, climate change in Uzbekistan manifests itself directly in the disappearance of existing snow masses in mountain ranges (MWR, 2020). These masses constitute the supply of the main rivers of the region. In the last 50 years, glaciers have been reduced by approximately $30 \%$. It is estimated that when the temperature increases by $2{ }^{\circ} \mathrm{C}$, the volume of ice will decrease by $50 \%$, and by $4{ }^{\circ} \mathrm{C}$, by $78 \%$. Such melting of glaciers could lead to severe water shortages. According to estimates, by 2050 the flow in the Syr Darya basin is expected to decrease by 5\%, 
International Journal of Agriculture and Environmental Research

ISSN: 2455-6939

Volume: 06, Issue: 03 "May-June 2020"

and in the Amu Darya basin by 15\%. For 2015, the total water deficit in Uzbekistan will be more than $3 \mathrm{~km}^{3}$, by 2030 it will increase to $7 \mathrm{~km}^{3}$ and by $2050,15 \mathrm{~km}^{3}$.

Assessments carried out with the help of global climate models show that climate change will exacerbate water scarcity in Uzbekistan (World Bank, 2013). This will lead to an increase in the duration and duration of droughts in 2000, 2008, 2011, 2014 and 2018. Meeting the economy's needs for water resources during droughts can be critical to the country.

The water scarcity situation is further complicated by the fact that Uzbekistan is highly dependent on the water supply from neighboring countries (Sokolov, 2019). That is why Uzbekistan is establishing water relations with neighboring countries multilaterally and bilaterally.

In recent years, water relations between the two countries have improved significantly. There is a positive trend in addressing the problems of transboundary water use. The construction of new hydroelectric facilities and water reservoirs on the upper reaches of the Amu Darya River and the Syr Darya will help develop the Central Asia region, including Uzbekistan. Currently, existing water resources are not fully utilized. This allows for further development in the areas irrigated by the Amu Darya River and the Syr Darya River. It should also be borne in mind that the Aral Sea Basin needs to improve its legal research framework for the use of water resources (Bekchanov et al., 2018).

\section{Institutional problems of water management}

The main institutional problems of water management in Uzbekistan are the lack of incentives for water users. The users are mainly agricultural producers and individuals, those responsible for the infrastructures and those organized by their management (FAO, 2012). One reason may be that water users and the public do not participate in water resource management and do not have free access to information on water use.

Until now, administrative methods have dominated the management of water supply in the agricultural sector, without considering market factors. The main means of water distribution are based on quotas and administrative controls. The tasks of implementing cotton production and processing plans were not linked to maximizing economic benefits. It was also important to study the increase in income, in the efficiency of water use in agriculture and in reducing the cost of water supply. The main costs of water supply for agricultural producers are covered by the state budget. Payments for water supply by agricultural producers are not directly related to the amount of consumption. Its quantity is not enough to encourage efficient and economical water consumption (MWR, 2020). The management of the trunk and intercultural infrastructure is carried out mainly by the structures of the Ministry of Water Resources and is financed from the 
state budget. Implementers do not have sufficient incentives to save on the cost of introducing water and energy saving technologies, maintaining and modernizing infrastructure (Rakhimov and Yavmutov, 2019). Public-private partnership practices are not yet sufficiently applied in the sector. Water Consumers Associations have been established in order to effectively manage and distribute water in the farm's internal irrigation networks. But it has not yet been possible to create a sustainable structure for the self-management of water consumers.

The lack of efficiency of the work of the water consumers associations has caused a deterioration and obsolescence in the technical conditions of the irrigation networks and their hydraulic structures (Abdullaev et al., 2019). In addition, water supply services, in quantity and quality, have not been provided to farms.

This situation reflects a problem in planning the irrigated area. The average annual expenditure on irrigation is $\$ 60$ billion to irrigate 4.250 thousands hectares (Rahimov and Abdughaniyev, 2009). Water is transported through open channels with increasing demand. This increase is a consequence of population growth, the expansion of new industries and construction.

Water losses in the water transport and distribution network are very high. Transport efficiency is $0,5-0,6$. This indicates that more than $40-50 \%$ of the water is lost before reaching the farm. Increasing the efficiency of transportation and irrigation systems is one of the important opportunities to save water (Neira et al., 2005). If we carry out irrigation in accordance with all agrotechnical and recovery requirements, this ratio can be increased to at least 0,85-0,9.

\section{DISCUSSION}

Loss of water at irrigation points leads to waste of water and causes extensive material damage. This problem worsens groundwater levels, salinizes soils, and worsens the recovery status of irrigated land. In addition, water losses force oversize transport infrastructure. 


\section{Table 1: Distribution of funds allocated for reclamation activities in Uzbekistan (MWR, 2020).}

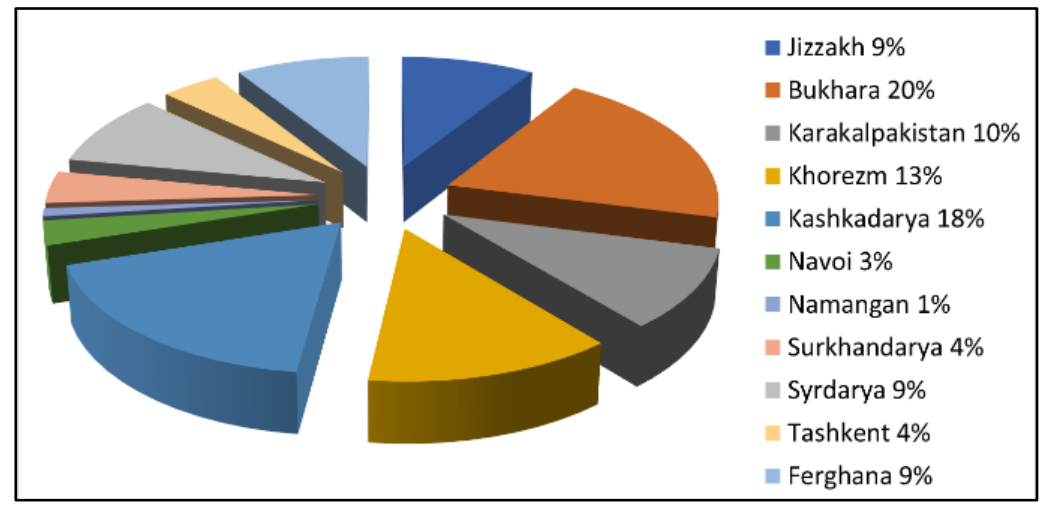

The efficient use of every cubic meter of water consumed remains an important scientific and practical problem. In recent years, the effective use of irrigation systems and reclamation funds; has been a priority in solving the problem. Careful maintenance, systematic repair and rational use of irrigation facilities, facilities and systems are carried out at the expense of the state budget (Table 1).

According to the data, as of January 1 (Rakhimov and Yavmutov, 2019), 2018, there are in Uzbekistan 4,3 million hectares of agricultural land and 2,2 million hectares of irrigated arable land with varying degrees of salinity (Table 2).

Table 2: Soil salinity in Uzbekistan (Rakhimov and Yavmutov, 2019).

\begin{tabular}{|c|c|c|}
\hline Degree of salinity & $10^{3}$ ha & $\%$ \\
\hline Low & 1373 & 62,5 \\
\hline Medium & 664 & 30 \\
\hline High & 163 & 7,5 \\
\hline
\end{tabular}

2020Steps are being taken to radically reform water use mechanisms, ensure their rational and efficient use, support and encourage the introduction of water saving technologies in various sectors of the economy. According Yavmutov and Rakhimov (2020), this will allow the recovery of irrigated land.

The measures taken, and the state support mechanisms, allowed the introduction of irrigation technologies that save water on 33.2 thousand hectares in 2019 alone (CAWater-IS, 2020). However, the area where new irrigation technologies are applied represents only $1.7 \%$ of the total area of irrigated land. For this reason, further intensification of measures is required to 
expand the use of water saving technologies in agriculture and guarantee water efficiency (MWR, 2020).

Modernization and improvement of irrigation is necessary. In other words, it is necessary to adopt new techniques for water distribution within the farm and to improve water distribution networks.

The advantages of using a modern drip irrigation system derive from the fact that only the root part of the plant is moistened. Therefore, the amount of water lost due to evaporation, runoff and deep percolation is reduced. Water consumption per hectare of cotton is 3,5 thousand $\mathrm{m}^{3}$ in drip irrigation, 8,5-9 thousand $\mathrm{m}^{3}$ in conventional irrigation, which saves 5-5,5 thousand $\mathrm{m}^{3}$ or 60 $65 \%$ of water. Table 3 shows the results of the transformation into drip irrigation in the cotton crop on 134 hectares of the "Rustam Fayz" farm in the Gijduvon district.

According to tests carried out in the field (MWR, 2020; Rakhimov and Yavmutov, 2019), drip irrigation saves electricity, labor, fuel, and other materials. Since this technique requires less water, less electricity or diesel is used to operate the pumps. Irrigation costs per hectare of cotton are 2,5-3 times, fuel consumption is 80-85 liters. The savings in the use of mineral fertilizers is estimated at $30-40 \%$. For a hectare of cotton cultivation with surface irrigation, $800 \mathrm{~kg}$ of nitrogen, $150 \mathrm{~kg}$ of phosphorus and $100 \mathrm{~kg}$ of potassium are needed. On the contrary, for a hectare in drip irrigation $300 \mathrm{~kg}$ of nitrogen, $150 \mathrm{~kg}$ of phosphorus and 50 of potassium are used. This is because in drip irrigation the absorption of mineral fertilizers is $90-95 \%$ and only $30-38 \%$ in conventional irrigation. During irrigation, dissolved fertilizers enter the root zone directly and nutrients are quickly absorbed.

Table 3: Comparative ACCOUNTING of cotton cultivation on the basis of drip irrigation technology by the farm "Rustam fayz" in Gijduvon district (MWR, 2020).

\begin{tabular}{|c|c|c|c|c|c|}
\hline Costs & $\begin{array}{c}\text { Unit of } \\
\text { measurement }\end{array}$ & $\begin{array}{l}\text { Surface } \\
\text { irrigation }\end{array}$ & Drip irrigation & $\begin{array}{c}\text { Absolut } \\
\text { difference }\end{array}$ & $\%$ \\
\hline \multirow{2}{*}{ Seeds } & mln. soum & 36 & 12 & -24 & \multirow{2}{*}{66,6} \\
\hline & $\mathrm{kg}$ & 8.040 & 2.680 & -5.360 & \\
\hline \multirow{2}{*}{$\begin{array}{l}\text { Mineral fertilizers } \\
\text { and chemical } \\
\text { services }\end{array}$} & mln. soum & 293 & 277 & -16 & \multirow{2}{*}{94,5} \\
\hline & tonnes & 121 & 77 & -44 & \\
\hline \multirow{2}{*}{$\begin{array}{l}\text { Consumption of } \\
\text { fuel and lubricants }\end{array}$} & mln. soum & 165 & 81 & -84 & \multirow{2}{*}{51,0} \\
\hline & tonnes & 29 & 14 & -15 & \\
\hline $\begin{array}{l}\text { Mechanization } \\
\text { service costs }\end{array}$ & mln. soum & 212 & 136 & -76 & 64,1 \\
\hline Salary (including & mln. soum & 415 & 612 & 196 & 147,5 \\
\hline
\end{tabular}


International Journal of Agriculture and Environmental Research

ISSN: 2455-6939

Volume: 06, Issue: 03 "May-June 2020"

\begin{tabular}{|c|c|c|c|c|c|}
\hline harvest) costs & & & & & \\
\hline Other expenses & mln. soum & 112 & 112 & 0 & 0 \\
\hline Production costs & mln. soum & 1.234 & 1.230 & -4 & 99,6 \\
\hline $\begin{array}{c}\text { Investment costs } \\
\text { for drip irrigation } \\
\text { technology }\end{array}$ & mln. soum & - & 2.627 & & \\
\hline $\begin{array}{c}\text { Annual cost of drip } \\
\text { irrigation (at the } \\
\text { expense of } \\
\text { coverage in 5 } \\
\text { years) }\end{array}$ & mln. soum & 525 & & \\
\hline TOTAL COSTS & mln. soum & 1.234 & 1.755 & 521 & 14,2 \\
\hline
\end{tabular}

With early maturation of the crop, high yield and product quality are observed in drip irrigation. Due to the precise entry of moisture into the plant root system and the complete assimilation of fertilizers, the yield is $50-55 \%$ higher than with conventional irrigation.

Drip irrigation does not require drainage infrastructure, so arable land is increased by an area of $10 \%$. In addition, the soil structure is preserved since salts do not rise with the rise of the groundwater level.

The different absorption of water in the soil allows irrigation with very uneven surfaces. The location of the irrigation drippers at the top of the furrows facilitates the mechanization of the soil. The soil between the rows remains dry throughout the season, facilitating the movement of farm machinery and workers.

This irrigation technique favors the growth control of adventitious weeds. In addition, the cotton root develops well, many active radical hairs are formed, and the rate of nutrient consumption with water increases. The area of drip-irrigated land of legal entities that have introduced drip irrigation is exempt from the one-time land tax for a period of 5 years. This benefit is on average 130-150 thousand soums per hectare (Table 4). 
International Journal of Agriculture and Environmental Research

ISSN: 2455-6939

Volume: 06, Issue: 03 "May-June 2020"

Table 4: Costs and Benefits of a cotton crop based on drip irrigation technology from the "Rustam fayz" farm in the Gijduvon district (MWR, 2020).

\begin{tabular}{|c|c|c|c|c|}
\hline Costs & $\begin{array}{c}\text { Unit of } \\
\text { measurement }\end{array}$ & Surface irrigation & Drip irrigation & Difference \\
\hline 1 hectares costs & thousand soum & 9.207 & 13.097 & 3.890 \\
\hline Earnings per 1 ha & thousand soum & 9.425 & 14.625 & 5.200 \\
\hline $\begin{array}{c}\text { NET BENEFIT } \\
\text { per 1 hectare }\end{array}$ & thousand soum & 268 & 1.528 & 1.260 \\
\hline Profitability & $\%$ & 2,4 & 11,7 & 9,3 \\
\hline
\end{tabular}

In this sense, in the Decree of the President of the Republic of Uzbekistan "On measures for the efficient use of land and water resources in agriculture" (NAPM, 2020), approved in 2019 as a future objective the introduction of new irrigation technologies on 253,381 hectares for the period 2019-2022.

Table 5: Forecast indicators for the introduction of drip irrigation in cotton fields in the districts of Bukhara region in 2019 in hectares

\begin{tabular}{|c|c|c|}
\hline Districts & Total cotton fields & $\begin{array}{c}\text { Forecast indicators } \\
\text { of drip irrigation }\end{array}$ \\
\hline Bukhara & 8.558 & 400 \\
\hline Vobkent & 9.560 & 400 \\
\hline Jondor & 11.910 & 400 \\
\hline Kogon & 6.722 & 500 \\
\hline Karakul & 8.758 & 600 \\
\hline Korovulbozor & 4.965 & 300 \\
\hline Olot & 7.851 & 1.000 \\
\hline Peshku & 8.120 & 500 \\
\hline Romitan & 10.845 & 1.000 \\
\hline Shofirkon & 92.47 & 400 \\
\hline Gijduvon & 9.744 & 500 \\
\hline Bukhara city & 12.050 & 0 \\
\hline Total in region & 96.400 & 6.000 \\
\hline
\end{tabular}

As a result of this program, the area of critical groundwater levels up to 2 meters has been reduced by 364,6 thousand hectares. In the Republic of Karakalpakstan, this figure decreased by 59,1 thousand hectares, 45,6 thousand hectares in the Syrdarya region, 46,2 thousand hectares in the Tashkent region and 34,4 thousand hectares in the Bukhara district (CAWater-IS, 2020). This 
International Journal of Agriculture and Environmental Research

ISSN: 2455-6939

Volume: 06, Issue: 03 "May-June 2020"

decrease in water levels has allowed an increase in cotton yields from 2 to 4 quintals per hectare and in cereals from 4 to 6 quintals per hectare (MWR, 2020).

In the areas where land reclamations were executed, the area of strong and moderate salinity decreased by 81,2 thousand hectares. This improvement can be quantified by measuring the level of groundwater mineralization that decreased. The groundwater area with a mineralization level of up to $1 \mathrm{~g} /$ meter increased by 74 thousand hectares.

In recent years, 753 billion soums have been allocated for the implementation of the Program. (equivalent to about 792 thousand USD), of which 312,2 billion souls were allocated for investment projects, 315,6 billion soums for soum repair and restoration and 125,7 billion soums for the purchase of recovery equipment.

As a result, all measures to improve the reclamation of lands under the program have been fully implemented. The task now is to prevent the deterioration of land reclamation and to prevent the deterioration of land reclamation.

The state is focusing on the implementation of measures to improve and repair the irrigation and irrigation system for 2021-2025. It is also to introduce a mechanism to encourage the development and widespread implementation of modern technologies for drip irrigation and other advanced water conservation. Strict measures should be taken to introduce market mechanisms in water resources management. The use of drip irrigation and other non-traditional methods should improve the quality of agro-technical measures in this regard.

\section{CONCLUSION}

In the context of market relations, in order to increase the efficiency of the use of irrigation facilities, it is necessary to pay close attention to the following tasks:

- Improving the condition of existing major trunk canals, dams, dams, reservoirs, irrigation systems and networks;

- Improving the efficiency of collector-drainage networks and pumping stations;

- Increasing the rational use of water resources, reducing the evaporation and filtration of water;

- Economical irrigation methods - the introduction of technologies such as drip, rain irrigation and widespread use of underground irrigation;

- Scientific solution of economic problems, such as determining the book value of facilities in irrigation systems, the introduction of depreciation allocation principles, setting the price per hectare or one cubic meter for wastewater supplied through the irrigation system; 
International Journal of Agriculture and Environmental Research

ISSN: 2455-6939

Volume: 06, Issue: 03 "May-June 2020"

- Strengthening the state regulatory policy in the field of water management construction in connection with the conservation of land and water resources;

In order to increase the efficiency of the main irrigation, irrigation and reclamation funds in the water management construction complex, it is necessary to pay close attention to clearly defining the rate of depreciation.

Therefore, future lines should include aspects such as the computerization of water supply and reservoir facilities, the establishment of open and closed canals and collectors, new pumping stations and drainage facilities and energy supply networks. For this it is necessary to define with scientific criteria the competencies and functions of the elements necessary for water management. And it is necessary to introduce a scientific understanding of economic concepts related to water management.

\section{REFERENCES}

Abdullaev, I, J. Kazbekov, H. Manthritilake and K. Jumaboev. 2009. Water User Groups in Central Asia: Emerging Form of Collective Action in Irrigation Water Management. Water Resources Management 24(5):1029-1043.

Askarov, A.A. 1981. Southern Uzbekistan in the Second Millennium D. C. Soviet Anthropology and Archeology 14 (1): 5-26.

Bartold, V.V. 1925. History of research on the Orient in Europe and Russia: Lectures given at the university and at the Institute of Living Eastern Languages. Leningrad.

Bekchanov, M., C. Ringler and A. Bhaduri. 2018. A Water Rights Trading Approach to Increasing Inflows to the Aral Sea. Land Degradation \& Development 29 (4): 952-961.

CAWater-IS. 2020. Regional Information System on Water and Land Resources in the Aral Sea Basin. http://cawater-info.net/bd/index_e.htm.

FAO. 2012. AQUASTAT Country Profile-Uzbekistan. Food and Agriculture Organization of the United Nations (FAO). Rome, Italy.

Gulyamov, Y.G. 1979. Bukhara Nur. Ethnography and archeology in Central Asia, ed. by Vinogradov A.V., Vorob'eva M.G., Itina M. A., Levina L.M., Nerazik E. E., Rapoport Y.A, Science, Moscow.

MWR. 2020. Ministry of Water Resources of the Republic of Uzbekistan. http://www.water.gov.uz/uz 
International Journal of Agriculture and Environmental Research

ISSN: 2455-6939

Volume: 06, Issue: 03 "May-June 2020"

NAPM, 2020. Decree of the President of the Republic of Uzbekistan of June 17, 2019 No. PF5742 "On measures for the efficient use of land and water resources in agriculture". National agency of project management under the President of the Republic of Uzbekistan.

Neira X.X., C.J. Álvarez, T.S. Cuesta and J.J. Cancela. 2005. Evaluation of water use in traditional irrigation: an application to the Lemos valley irrigation district, northwest of Spain. Agricultural Water Management 75 (2): 137-151.

Kogay N.A. 1969. Physical and geographical zoning of the Turan part of Central Asia. Tashkent.

Rahimov, O. and A. Abdughaniyev. 2009. Management of water resources and their division problems in Central Asian region. V Congreso Nacional y II Congreso Ibérico Agroingeniería 2009, 28-30 septiembre, Lugo (España)

Rakhimov, O. and D. Yavmutov. 2019. Economics of agro-industrial complex: agricultural land and water resources and their use. Economics: agriculture, microeconomics, macroeconomics. Tashkent.

Sokolov, V. 2019. 25 Years of activities International Fund for Saving the Aral Sea and new impulses for development of the Aral Sea Region. Agency of International Fund for Saving the Aral Sea. Taskhent.

Tolstov, S.P. 1962. Along the Ancient Deltas of the Oxus and Jaxartes. Izdatel'stvo Vostochnoy Literaturii, Moscow.

Toshov H.R. and I.E. Mirzaev. 2016. Climate and economy: its consequences on the example of the Bukhara region. Republican Scientific-methodological and Educational Journal 2 (18): 11-13.

Yakubovsky, A. and A. Nekrasov. 1930. Gorodishche Mizdakhkan. Zapiski Kollegii Vostokovedov 5: 551-580.

Yavmutov, D.Sh. and O. Rakhimov. 2020. Elaboration of regional strategies for the development and improvement of land and water in agriculture. Academy 2 (53).

World Bank. 2013. Strengthening Analysis for Integrated Water Resources Management in Central Asia: A Road Map for Action. Main Report. 